Jurnal Konstruksi Hukum | ISSN: XXXX | E-ISSN: XXXX Vol. 1, No. 1, September 2020 Hal. 164-169| Available online at https://www.ejournal.warmadewa.ac.id/index.php/jukonhum

DOI: https://doi.org/10.22225/jkh.1.1.2150.164-169

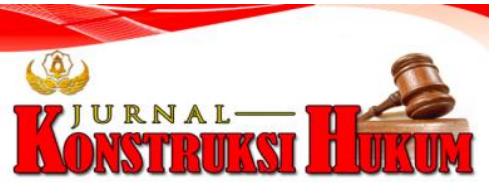

\title{
FUNGSI PARTAI POLITIK DALAM PENDIDIKAN POLITIK MASYARAKAT
}

\author{
I Gede Wijaya Kusuma, Ida Ayu Putu Widiati, Luh Putu Suryani \\ Fakultas Hukum Universitas Warmadewa, Denpasar-Bali, Indonesia
}

\begin{abstract}
Abstrak
Salah satu fungsi partai politik dalam legislasi adalah sebagai sarana pendidikan dan sosialisasi politik. Partai politik wajib mensosialisasikan wacana politiknya kepada publik. Namun dalam implementasinya di lapangan, masih ada partai politik yang belum memaksimalkan fungsinya dalam melakukan pendidikan politik kepada publik. Studi ini membahas mengenai (1) Apa fungsi partai politik dalam memberikan pendidikan politik publik dan pengaruhnya terhadap partisipasi publik dalam pemilihan umum? (2) Apa implikasi partai politik yang tidak melaksanakan pendidikan politik publik?. Penelitian ini dilakukan dengan menggunakan metode penelitian hukum normatif, sumber bahan hukum primer dan sekunder, metode pengumpulan bahan hukum menggunakan pencatatan undang-undang dan lainnya, serta menganalisis bahan hukum menggunakan metode analisis deskriptif. Hasil penelitian ini menunjukkan bahwa menurut Undang-Undang Nomor 2 Tahun 2011 salah satu fungsi partai politik adalah memberikan pendidikan politik sebagai sarana pendidikan bagi masyarakat luas untuk menjadi warga negara Indonesia yang sadar akan hak dan kewajibannya di depan umum. Pentingnya pendidikan politik yang dilakukan oleh partai politik secara maksimal dan pada esensi aktualnya akan dapat memiliki dampak yang sangat baik terhadap masyarakat, yang berarti bahwa masyarakat mampu menjadi orang yang sadar akan kewajibannya dalam memberikan pilihan kepada partai politik atau kandidat yang benar dan tulus dalam hal kesejahteraan rakyat. Implikasi dari partai politik yang tidak melaksanakan pendidikan politik publik adalah untuk menyebabkan penurunan partisipasi publik dalam pemilihan umum dan ini juga akan menyebabkan kondisi politik yang tampaknya tidak sehat dan memungkinkan abstain tinggi karena rendahnya tingkat partisipasi publik.
\end{abstract}

Kata kunci : Fungsi partai politik; Implikasi; Pendidikan politik

\begin{abstract}
One of the functions of political parties in legislation is as a means of political education and socialization. Political parties are obliged to disseminate their political discourse to the public. However, in its implementation in the field, there are still political parties that have not maximized their function in providing political education to the public. This study discusses (1) What is the function of political parties in providing public political education and its influence on public participation in general elections? (2) What are the implications of political parties that do not implement public political education? This research was conducted by using normative legal research methods, primary and secondary sources of legal materials, methods of collecting legal materials using statute records and others, and analyzing legal materials using descriptive analysis methods. The results of this study indicate that according to Law No.2 of 2011, one of the functions of political parties is to provide political education as a means of education for the wider community to become Indonesian citizens who are aware of their rights and obligations in public. The importance of political education carried out by political parties to the maximum and in its actual essence will be able to have a very good impact on society, which means that people are able to become people who are aware of their obligations in giving choices to political parties or candidates who are true and sincere in terms of welfare. people. The implication of political parties that do not carry out public political education is to cause a decrease in public participation in general elections and this will also lead to apparently unhealthy political conditions and allow high abstention due to low levels of public participation.
\end{abstract}

Key words: Political party function; Implication; Political education

\section{PENDAHULUAN}

Indonesia adalah menganut demokrasi, dimana negara menjamin partisipasi masyarakat dalam dan kehidupan politik secara bebas, tanpa tekanan tetapi masih dalam koridor hukum dan hukum (Amal, 2014). Demokrasi adalah salah satu bentuk kebebasan seseorang atau warga negara untuk ikut serta dalam menyampaikan aspirasinya (Edward et al., 2019; Sarbani, 2013). Demokrasi akan 
melahirkan supremasi hukum yang merupakan dasar prinsip aturan hukum negara demokratis yang berkeadilan social (Asshiddiqie, 2005). Demokrasi di Indonesia dituangkan melalui pemilihan secara langsung. Dengan ini maka diharapkan aspirasi masyarakat akan tersampaikan dengan baik dan memenuhi harapan masyarakat. Adapun prinsip demokrasi seperti yang disebutkan oleh J.B.J.M Ten Berge adalah sebagai berikut (HR, 2002; Muntoha, 2009).

a. Kekuatan tertinggi yang dimiliki oleh sebuah negara diputuskan melalui pemilihan langsung.

b. Adanya transparansi organisasi pemerintahan dalam menjalankan tugasnya.

c. Distribusi wewenang, konsentrasi kekuasaan dalam masyarakat dalam satu organ pemerintahan adalah arbitrer. Karena itu, otoritas badan publik harus tersebar di berbagai organ.

d. Pengawasan dan kontrol, tata kelola harus dikendalikan.

e. Keterbukaan pada publik.

f. Hak menyampaikan aspirasi.

Dalam Undang-Undang Nomor 2 Tahun 2011 tentang Partai Politik disebutkan bahwa: "partai politik adalah organisasi yang bersifat nasional dan dibentuk oleh sekelompok warga Negara Indonesia secara sukarela atas dasar kesamaan kehendak dan cita-cita untuk memperjuangkan dan membela kepentingan politik anggota, masyarakat, bangsa dan Negara, serta memelihara keutuhan Negara Kesatuan Republik Indonesia berdasarkan Pancasila dan Undang-Undang Dasar Negara Republik Indonesia Tahun 1945”.

Partai-partai politik adalah cermin kebebasan berserikat dan kebebasan berserikat serta kebebasan berekspresi (Ritonga, 2015), keberadaannya dilindungi oleh konstitusi dalam demokrasi konstitusional. Partai politik juga merupakan elemen penting dalam pembentukan aturan hukum yang demokratis. Dalam perwakilan preventif politik dalam lembaga formal negara, partai memiliki peran dan posisi strategis (Natalia, 2015; Ristyawati, 2019). Demokrasi prosedural dan substansial akan selalu menempatkan aktor politik utama yaitu partai politik sebagai instrumen yang menentukan jalannya pemilihan umum. Fungsi partai politik disebutkan dalam UndangUndang Nomor 2 Tahun 2011, tepatnya di Pasal 11 ayat (1).

Keberadaan partai politik itu peting dalam menunjang berjalannya pemerintahan yang demokrasi. Dimana partai politik adalah salah satu pihak yang mampu menjembatani antara pemerintah dengan masyarakat. Hal ini sesuai dengan yang tertuang dalam Undang-Undang Dasar 1945 yaitu di Pasal 6A ayat (2) yaitu sebagai berikut: "Pasangancalon Presiden dan Wakil Presiden diusulkan oleh partai politik atau gabungan partai politik peserta pemilihan umum sebelum pelaksanaan pemilihan umum."

Meskipun fungsi dari partai politik merupakan hal yang sangat penting tetapi kinerja dari partai politik dalam menjalankan pendidikan partai politik belum maksimal di masyarakat, sehingga masih terdapat masyarakat yang tidak paham akan hukum dan yang mampu menggunakan hak pilihnya dalam pemilihan umum. Keberadaan partai politik berfungsi sebagai alat komunikasi politik antara pemerintah dan yang diperintah, yaitu masyarakat. Dikumpulkan dengan fungsi partai politik dalam memberikan pendidikan politik publik, diatur dalam beberapa peraturan yang berlaku. Atas uraian diatas, maka rumusan permasalahan yang dibahas yaitu bagaimanakah fungsi partai politik dalam memberikan pendidikan politik masyarakat dan pengaruhnya terhadap partisipasi masyarakat dalam pemilihan umum dan bagaimanakah implikasi partai politik yang tidak melaksanakan pendidikan politik masyarakat.

\section{METODE PENELITIAN}

Metode yang digunakan dalam penelitian ini adalah hukum normatif. Pendekatan masalah digunakan dalam memecahkan masalah dalam penelitian ini adalah pendekatan hukum dan konseptual. Pendekatan hukum dilihat dari hukum dan peraturan yang ada, sedangkan pendekatan konseptual dilihat dari konsep hukum lain yang digunakan untuk membantu menyelesaikan masalah yang terjadi. Pengumpulan bahan hukum dilakukan dengan menggunakan metode studi dokumen, yaitu dengan mempelajari bahan primer dan sekunder dalam sumber bacaan yang relevan dengan masalah yang sedang dibahas. Analisis bahan hukum diperoleh dan dikumpulkan dan diproses dengan menganalisis interpretasi dan kemudian disajikan secara deskriptif analitis. 


\section{HASIL DAN PEMBAHASAN}

\section{1. $\quad$ Fungsi Partai Politik dalam Memberikan Pendidikan Politik Masyarakat}

Partai politik adalah salah satu pendukung dari suksesnya negara demokrasi. Partai politik akan mampu menjalankan perannya dengan efektif apabila ada tanggung jawab bersama antara partai politik itu sendiri dengan masyarakat luas. Untuk itu maka partai politik seharusnya mampu menjalankan pendidikan politik kepada masyarakat seperti yang telah ditetapkan dalam peraturan perundang-undangan yang berlaku, yaitu dalam Undang-Undang Nomor 2 Tahun 2011 Tentang Partai Politik. Partai politik adalah sarana atau wadah bagi masyarakat untuk berkumpul dan menyalurkan aspirasi yang dimiliki untuk proses pembangunan negara yang berkeadilan dan makmur. Sistem politik Indonesia beberapa dekade terakhir telah menempatkan partai politik sebagai salah satu pilar pendukung demokrasi yang nyata. Kehadirannya ditengah-tengah masyarakat menjadi salah satu konsekuen yang mampu memberikan kekuatan politik bagi masyarakat melalui fungsi-fungsi yang dijalankannya.

Salah satu fungsi yang dijalankan adalah fungsi pendidikan politik masyarakat. Pendidikan politik adalah proses pemberikan pengetahuan kepada masyarakat mengenai politik negara dan akhirnya terimplementasi pada kegiatan pemilihan umum. Sukses atau tidaknya pendidikan politik yang dilakukan oleh partai politik kepada masyarakat dapat dilihat dengan tingkat partisipasi masyarakat ketika pemilihan umum, semakin sedikit masyarakat yang Golput maka semakin sukses partai politik dalam melakukan pendidikan partai politik kepada masyarakat. Hal ini mengingat pendidikan partai politik itu pada dasarnya adalah membentuk dan menumbuhkan orientasi politik individu (Rusadi, 2004). Pasal 31 Undang-Undang Nomor 2 Tahun 2011 menyebutkan bahwa:

Pendidikan partai politi bertujuan untuk: Pertama, meningkatkan kesadaran akan hak dan kewajiban masyarakat dalam kehidupan bermasyarakat, berbangsa dan bernegara. Kedua, meningkatkan partisipasi politik dan inisiatif masyarakat dalam kehidupan masyarakat, bangsa dan negara. Ketiga, meningkatkan kemandirian, kematangan, dan membangun jiwa nasional untuk menjaga persatuan nasional. Dimana pendidikan politik dilakukan untuk membangun budaya etis dan politik yang sesuai dengan Pancasila. Selanjutnya Pasal 34 ayat (3a) menjelaskan bahwa: dalam pelaksanaan pendidikan politik, partai politik menerima bantuan keuangan yang bersumber dari Anggaran Pendapatan dan Belanja Negara / Anggaran Pendapatan dan Belanja Daerah yang diberikan secara proporsional kepada partai politik yang mendapat kursi di Dewan Perwakilan Rakyat, Dewan Perwakilan Rakyat Daerah Provinsi, yang perhitungannya didasarkan pada jumlah suara akuisisi. Bantuan keuangan diprioritaskan untuk melakukan pendidikan politik bagi anggota partai politik dan masyarakat.

Pendidikan partai politik harus dilakukan oleh partai politik kepada masyarakat mengingat bahwa banyak masyarakat yang masih awam mengenal politik. Dibeberapa kalangan masyarakat bahkan ada yang merasa takut untuk terjun ke dunia politik. Bukan karena apa, hal ini terjadi karena kurang paham dan sadarnya masyarakat akan politik itu sendiri. Politik sebenarnya tidaklah seram dan kegiatan yang salaing menjatuhkan. Justru dengan keberadaan politik yang sebenarnya mampu menjadikan keadaan menjadi stabil baik itu dari sisi keamanan ataupun pertahanan negara. Politik apabila digunakan dengan baik maka akan memberikan dampak yang positif pula bagi kehidupan berbangsa dan bernegara. Tetapi keberadaan paradigma di masyarakat menjadikan politik dianggap sebagai sesuatu yang menyeramkan dan jarang ada yang mau mengerti dan memahami politik itu sendiri.

Berjalannya suatu negara tidak akan bisa mencapai kondisi yang kondusif apabila tidak berjalan beriringan dengan politik. Hal ini karena politik adalah salah satu stabiliser yang menjalankan fungsinya dalam menopang pembangunan ekonomi di suatu daerah. Misalnya adalah, seorang investor luar negeri atau investor asing akan menanamkan modal atau berinvestasi ketika negara tersebut berada pada kondisi kestabilan politik dan keamanan disuatu daerah, selain melihat kondisi ekonominya. Untuk itu maka sudah seharusnya masyarakat paham dan mengerti dengan dunia politik sehingga politik yang ada akan menjadi politik yang berkualitas dengan melibatkan partisipasi masyarakatnya dalam pengambilan keputusan.

Adapun fungsi dalam melakukan pendidikan politik kepada masyarakat dilakukan oleh Partai Politik. Pendidikan politik akan sukses apabila sebagaian besar masyarakat di daerah tersebut mampu untuk berpartisipasi dalam politik dan dalam pengambilan keputusan. Keikutsertaan 
masyarakat dalam politik, riilnya dapat dilihat pada saat pemilihan umum secara langsung, baik itu dalam pemilihan umum. Semakin tinggi angka partisipasi dan semakin rendahnya angka Golput dalam kegiatan tersebut maka menunjukkan bahwa Partai politik berhasil dalam menjalankan fungsinya dalam memberikan pendidikan politik kepada masyarakat.

Pendidikan politik kepada masyarakat dapat dilakukan dengan berbagai kegiatan, dapat berupa kegiatan formal ataupun non formal. Bentuk kegiatannya seperti dengan melakukan seminar, lokakarya, pelatihan, jambore ataupun kegiatan positif lainnya. Partai politik harus mampu memberikan pendidikan politik kepada semua golongan, baik itu generasi muda hingga generasi tua, pada setiap lini masyarakat. Hal ini guna menjadikan negara lebih baik dan tidak menimbulkan keberadaan rasa ketidakadilan pada benak masyarakat. Terlebih ketika ada diposisi yang kurang baik, apabila masyarakat telah mampu mengerti tentang politik maka bukannya sikap saling menyalahkan yang akan tercipta, tetapi justru sikap saling dukung dan tidak menyalahkan keputusan yang diambil oleh Pemerintah.

Partai politik adalah salah satu pilar demokrasi yang nyata dan keberadaan sangat penting terutama dalam menjalankan fungsinya. Salah satu fungsinya adalah dalam kegiatan pendidikan politik masyarakat. Pendidikan politik masyarakat dapat menjadi salah satu pendongkrak meningkatnya partisipasi masyarakat dalam kegiatan pemilihan langsung baik itu untuk memilih presiden atau wakil presiden, memilih Dewan Perwakilan Rakyat atau Dewan Perwakilan Rakyat Daerah. Fungsi partai politik pada dasarnya dapat diselenggarakan melalui beberapa kegiatan di antaranya seperti seminar, lokakarya, pelatihan dan kegiatan lainnya. Partai politik memiliki fungsi untuk melakukan pendidikan politik dengan harapan agar masyarakat mengerti dan paham akan politik di suatu negara. Tetapi, segala sesuatunya kembali lagi pada masyarakat itu sendiri. Hal ini karena kesadaran tumbuh dari diri personal masyarakat itu sendiri bukan atas paksaan atau himbauan orang lain, termasuk partai politik tidak bisa memaksa masyarakat untuk paham dan mengerti dalam berpolitik.

Untuk itu maka partai politik sebaiknya dalam melakukan pendidikan politik mampu menggunakan pendekatan-pendakatan yang efektif agar mampu menyentuh semua golongan masyarakat. Hal ini akan menjadi salah satu cara yang mampu mendorong kondusifnya keadaan politik masyarakat. Ketika masyarakat paham dan mengerti dengan hukum yang berlaku maka masyarakat akan menghargai pemerintahan dan mampu ikut menjadi garda depan politik negara. Ikut berpartisipasi dalam politik berarti ikut mendukung politik di negara tersebut. Suatu negara yang maju adalah suatu negara yang mampu menjaga stabilitas politik dan keamanan negaranya. Untuk itu maka seharusnya semua masyarakat mau dan ikut dengan berbagai kegiatan yang dilakukan oleh partai politik dalam upayanya melakukan pendidikan politik kepada masyarakat, seperti kegiatan sosialisasi atau penyuluhan.

\section{Implikasi Partai Politik Yang Tidak Melaksanakan Pendidikan Politik Masyarakat}

Partai politik memiliki posisi penting dalam konstitusi. Salah satu fungsi partai politik adalah pendidikan politik. Namun, partai politik belum melakukan pendidikan politik secara penuh baik publik maupun internal partai. Partai politik memiliki tiga fungsi, yaitu mempersiapkan kader untuk kepemimpinan nasional di cabang legislatif dan eksekutif, menyalurkan aspirasi rakyat, dan melakukan pendidikan politik. Pendidikan politik untuk partai politik internal terlihat dalam regenerasi. Ini berarti bahwa jika partai politik telah melakukan pendidikan politik secara maksimal, ini akan memiliki dampak yang baik dalam pemilihan. Ini karena pendidikan politik kepada publik dapat mendorong orang untuk berpartisipasi dalam politik atau berpartisipasi dalam pemilihan. Namun realisasinya dalam pemilihan, pemilih memilih karena identitas atau agama. Ini diindikasikan terjadi karena partai politik dan negara tidak memberikan pendidikan politik.

Pendidikan politik memiliki peran penting dalam membentuk kualitas individu yang sadar akan hak dan kewajiban mereka di dunia politik dan partisipasi mereka dalam pemilihan. Hubungan antara pendidikan politik dan partisipasi politik yang baik akan memunculkan individu yang memiliki tanggung jawab dan secara aktif mengikuti perkembangan politik. Partisipasi politik yang tidak didasarkan pada pendidikan politik akan memunculkan individu yang tidak memiliki rasa tanggung jawab dan tidak memiliki bahwa mereka memiliki hak dan kewajiban untuk bersamasama menentukan jalan demokrasi di negara mereka. Oleh karena itu, pendidikan politik 
diharapkan dapat membuat individu bertanggung jawab dan cerdas dalam merespons politik yang ada.

Partai politik berperan dalam melakukan pendidikan politik sesuai dengan yang diatur dalam peraturan perundang-undangan yang berlaku. Adapun bentuk dari penyelenggaraan pendidikan politik masyarakat adalah dengan melakukan baik itu kampanya ataupun melalui kaderisasi partai. Pada dasarnya sebenarnya banyak metode yang dapat dilakukan dalam menjalankan fungsinya dalam pendidikan politik masyarakat. Dalam hal ini tentunya harus ada sinergis antara partai politik itu sendiri dengan masyarakat sebagai objek dan subjek penyelenggara.

Kader partai politik adalah ujung tombak penyelenggaraan pendidikan politik yang dilakukan oleh masing-masing partai. Kader partai politik memiliki kewajiban dan tugas untuk membantu masyarakat dalam menyelesaikan masalah politik. Semua kader partai politik memiliki tugas yang sama untuk mengajarkan pendidikan politik kepada publik. Penyelenggaraan pendidikan politik dapat menjadi salah satu bentuk esensi nyata untuk membentuk jiwa masyarakat yang paham dan sadar hukum. Pendidikan politik yang baik dan benar akan menjadi kunci utama atas keberhasilan politik di suatu negara.

Organisasi pendidikan politik harus mampu meningkatkan kesadaran kehidupan nasional dan negara, kemampuan bangsa, pengembangan pribadi, pendidikan politik harus mampu meningkatkan kesadaran masyarakat untuk mengenali masalah politik yang belum terselesaikan. Bentuk pendidikan politik yang dilakukan oleh partai politik pada umumnya adalah dalam bentuk kampanye dan kegiatan regenerasi. Dengan menjalankan fungsinya dalam menyediakan pendidikan politik yang cerdas di masyarakat, termasuk dengan berbagai kegiatan seperti kampanye, layanan sosial, regenerasi dan kegiatan positif lainnya, itu akan membuat masyarakat lebih sadar dan partisipasi masyarakat dalam politik akan meningkat. Dalam menjalankan fungsinya, partai politik harus memilih pendekatan yang tepat untuk menghindari konflik di tengah-tengah masyarakat, karena pada dasarnya partai politik berfungsi untuk menemukan dan mengajar seorang berbakat dan juga masyarakat pada umumnya, untuk secara aktif berpartisipasi ikut serta berpolitik. Selain itu, partai politik juga mengadakan kreasi atau menyalurkan pendapat aspirasi masyarakat sedemikian rupa sehingga kebingungan pendapat di masyarakat berkurang.

\section{SIMPULAN DAN SARAN}

\section{Simpulan}

Salah satu fungsi partai politik yang dituangkan dalam Undang-Undang Nomor 2 tahun 2002 adalah mengenai pendidikan partai politik. Pendidikan partai politik berkaitan dengan pendalaman empat pilar bangsa dan negara, pemahaman tentang hak dan kewajiban warga negara, kaderisasi yang berkelanjutan. Pendidikan partai politik dapat berupa seminar dan lokakarya, pelatihan, bantuan, pelatihan dan bimbingan teknis, pertunjukan seni dan budaya, dokumenter, komposi dan kegiatan lainnya. Implikasi dari partai politik yang tidak melaksanakan pendidikan politik publik adalah untuk menyebabkan penurunan partisipasi publik dalam pemilihan umum dan ini juga akan menyebabkan kondisi politik yang tampaknya tidak sehat dan memungkinkan abstain tinggi karena rendahnya tingkat partisipasi masyarakat.

\section{Saran}

Saran penelitian ini yang dapat disampaikan oleh peneliti yaitu bagi partai politik sebaiknya lebih sering melakukan pendidikan politik kepada publik, tidak hanya menjelang pemilihan, tetapi partai politik berbondong- bondong untuk menjalankan program partai mereka. Sebagai forum aspirasi bagi masyarakat, maka fungsi sekretariat partai harus dimaksimalkan tidak hanya untuk secara simbolis bahwa partai ada di daerah tetapi juga berfungsi sebagaimana seharusnya bagaimana masyarakat ingin mengenal partai lebih dekat. jika sekretariat partai tidak pernah dibuka untuk umum, tepat sebelum pemilihan, sekretariat partai penuh dengan pendukung partai. Berikutnya partai politik sebaiknya memperhatikan hal-hal yang perlu dipenuhi dalam hal partai dan untuk melaksanakan tugas mereka sebagai anggota partai politik dengan baik, jika telah duduk di salah satu kursi dari Dewan. Partai politik semakin meningkatkan kualitas keanggotaan, baik dalam disiplin dan lain-lain, ini akan membuatnya lebih mudah untuk mencapai tujuan bersama. Meningkatkan kualitas keanggotaan tidak hanya didasarkan pada regenerasi, tetapi harus melihat apa 
yang harus dicapai dalam tujuan bersama, tidak hanya memprioritaskan kepentingan keanggotaan, tetapi mencapai tujuan bersama.

\section{DAFTAR PUSTAKA}

Amal, I. (2014). Teori-Teori Mutakbir Partai Politik. Tiara Wacana.

Asshiddiqie, J. (2005). Hukum Tata Negara dan Pilar-Pilar Demokrasi. Konstitusi Press.

Edward, M., Pahlevi, T., \& Amrurobbi, A. A. (2019). Pendidikan Politik dalam Pencegahan Politik Uang Melalui Gerakan Masyarakat Desa. 6(1), 141-152.

HR, R. (2002). Hukum Administrasi Negara. PT Raja Grafindo Persada.

Muntoha, M. (2009). Demokrasi Dan Negara Hukum. Jurnal Hukum Ius Quia Iustum, 16(3), 379395.

Natalia, A. (2015). Peran Partai Politik dalam Mensukseskan Pilkada Serentak di Indonesia Tahun 2015. Jurnal TAPIs, 11(1), 47-68.

Ristyawati, A. (2019). Penguatan Partai Politik sebagai Salah Satu Bentuk Pengadministrasian dan Pelembagaan Demokrasi. 2(4), 710-720.

Ritonga, R. (2015). Pembubaran Partai Politik Terhadap Sistem Demokrasi di Indonesia. NASPA Journal, 10(2), 1.

Rusadi, K. (2004). Sistem Politik Indonesia, Suatu Model Pengantar, Edisi Revisi. Sinar Baru Algensindo.

Sarbani. (2013). Kata Kunci : Demokratisasi, Kebebasan Memilih, Pemilihan Umum. Jurnal Inovatif, $\operatorname{VIII}(1)$. 